41-1 | 2016

Varia

\title{
The subversion of marriage law in Brian Merriman's Cúirt an Mheain Oíche
}

Anne-Marie O'Connell

\section{(2) OpenEdition \\ 1 Journals}

\section{Electronic version}

URL: http://journals.openedition.org/etudesirlandaises/4808

DOI: 10.4000/etudesirlandaises.4808

ISSN: 2259-8863

\section{Publisher}

Presses universitaires de Rennes

\section{Printed version}

Date of publication: 15 June 2016

Number of pages: 53-72

ISBN: 978-2-7535-5091-9

ISSN: 0183-973X

\section{Electronic reference}

Anne-Marie O'Connell, «The subversion of marriage law in Brian Merriman's Cúirt an Mheain Oíche », Études irlandaises [Online], 41-1 | 2016, Online since 15 June 2018, connection on 02 May 2019. URL: http://journals.openedition.org/etudesirlandaises/4808; DOI : 10.4000/etudesirlandaises.4808 


\title{
The Subversion of Marriage Law in Brian Merriman's Cúirt an Mheain Oíche
}

\author{
Anne-Marie O'Connell \\ Université Toulouse 1 Capitole
}

Abstract

$18^{\text {th }}$ century Ireland under the Penal Laws produced many poems deploring the country's fate under British rule. Brian Merriman, a hedge schoolmaster from Clare, published in $1780 \mathrm{a}$ long, satirical poem called Cúirt an Mheain Oíche satirizing men's subjection of women within marriage. This contribution will examine what marriage law said about the situation of women and how the poem criticizes its negative consequences on the women of Ireland as judged by a bawdy fairy court of law.

Keywords: marriage law, women, Brehon, sexuality, war of the sexes, satire

\section{Résumé}

Au XVIII siècle, l'Irlande des Lois Pénales a produit de nombreux poèmes déplorant la servitude du pays sous la férule anglaise. Brian Merriman, maître d'école itinérant originaire du comté de Clare, a composé en 1780 un long poème satirique, Cúirt an Mheain Oiche, critiquant la domination des femmes au sein du mariage. Le présent article met en regard les lois matrimoniales et leurs conséquences négatives sur les femmes d'Irlande selon une cour de justice grivoise présidée par la reine des fées.

Mots clés : lois matrimoniales, femmes, droit Brehon, sexualité, guerre des sexes, satire

Ireland in the $18^{\text {th }}$ century had been deprived of its political, religious, cultural and economic freedom. The Irish Earls had been forced into exile after 1692, land had been confiscated, Catholicism prohibited, access to education and public office denied to non-Anglicans. The court poets, who had lost the patronage of the Gaelic nobility, became hedge schoolmasters, but kept writing and circulating verse of haunting beauty lamenting the disappearance of the old Gaelic Order and urging for political action. In those poems called aislingi ${ }^{1}$, Ireland looked out for a foreign saviour to relieve her from her plight and lamented her state of utter destitution. In

1. The word literally means "vision". It refers to a long tradition in Irish poetry and, in the $18^{\text {th }}$ century, describes a dream in which the poet has the vision of a supernatural woman symbolizing Ireland, who tells him about her woes under English rule and predicts the coming of a royal saviour to relieve her from her subjection. 
such a gloomy context, Brian Merriman, a poet, schoolmaster and mathematician from Clare, wrote a long satire in verse in the form of an aisling. Instead of meeting the personification of captive Ireland urging her sons to rebel against the English oppressor, the poet is dragged by a hideous female bailiff to the fairy court of Queen Aoibheall. There he witnesses a confrontation between a young woman and an old man about the rights of Irish women to sex and marriage.

Cúirt an Mheain Oiche has long been considered a social satire about the war of the sexes by allowing the women to have the upper hand in the dispute. This tradition goes back to Aristophanes's Lysistrata (411 BC) or, in Ireland, Domhnall Ó Colmáin's Párliament na mBan, written in 1670 or $1697^{2}$. Using the weakest members of society, namely women or fools, would tone down the severity of the political or social criticism and divert the heavy hand of moral censorship. As a hedge schoolmaster, Merriman belonged to a class whose existence had been marginalized. They were sometimes persecuted by the authorities for spreading knowledge among the peasantry, in the same way as Catholic priests were criminalised by the Penal Laws. However, schoolmasters were also prone to spreading political ideals questioning the authority of the Catholic Church; its hierarchy consistently opposed the teachings of itinerant scholars. Only poetry could grant its author enough leeway to promote freedom of conscience and of expression in politics and morals. The best forum for such tongue-in-cheek activism turns out to be a court of law because any expression of social or political discontent borrows from the language of justice, equity and rights.

The poet's political motivation is clear from its adopted form: using the aisling form is a sure sign that one should go beyond its bawdy and sexually-explicit statements. Cúirt an Mheain Oiche is primarily the indictment of the institution of marriage, supported by a legal system that Merriman calls into question. Its structure can be summarized as follows:

The poet walks at morning in a beautiful countryside scenery (lines 1-30);

He falls asleep and meets a supernatural woman (lines 31-60);

She tells him of the evils afflicting Ireland, one of them being the growing number of unmarried women (lines 61-112);

She reveals that a fairy court will be in session to deal with this plight and drags the poet there (lines 113-149);

The court is in session: a young maid tells the assembly of the sorry fate of unmarried young women in Ireland (lines 150-356);

An old man rebuts these accusations and defends old husbands duped by their younger wives (357-678);

2. Ó Cuiv, Brian (ed.). Párliament na mBan. Dublin, Dublin Institute for Advanced Studies, 1977. 
The maid accuses men, the law and the Church of terrible faults that affect the foundation of marriage (679-924);

The fairy Queen decides that all unmarried men over the age of 21 should be punished by the women of Ireland; the poet is seized by a group of angry ladies because he is not married (lines 925-1090);

He suddenly wakes up from his dream (last six lines).

This contribution will examine the various aspects of marriage that contributed to the injustice meted out by women in the poem. Part one will discuss the issues that make the legal subjection of women possible and, more specifically, the roles ascribed to the spouses, land ownership and inheritance, parenthood and the legal status of children as well the absence of sexual rights for women. The second part will consider the manner in which the poem denounces the negative impact of marriage law on Irish society. It contends that it is morally flawed and socially unfair since it contributes to the impoverishment of the women from the landless classes. Finally, we will see that such an indictment of matrimonial structures is conducted from within the Irish society and its old legal structures. This explains why the poem is set inside a court of law that follows the old Brehon ${ }^{3}$ proceedings. In that context, the analysis will focus on the procedure used in the mock trial described in the poem (a fairy court presided over by a fairy queen). It will then examine the role of the Irish language as both a poetic and a legal force against unfair laws; thirdly it will study the description of satire as a legal remedy against injustice. In that respect, giving a voice to women corresponds to the rehabilitation of female sexuality and of natural law.

\section{Marriage as an unfair legal institution}

Cúirt an Mheain Oiche was written in $1780^{4}$, in a period of intense intellectual and political turmoil. And although Brian Merriman was not a star poet among the Anglo-Irish élite, he cannot have been unaware of the changes that were affecting Europe before and after the American Revolution. Indeed hedge schoolmasters would naturally be inclined to get information and propagate it among their students. Thus Merriman, who had never travelled far and wide, adopted liberal ideas when it came to the fate of women within marriage ${ }^{5}$. He reproached matrimonial law with depriving women of equal rights within marriage, especially

3. The word comes from the Irish "breitheamh", which means "judge". For more legal definitions, see [http://www. duhaime.org/LegalDictionary/B/Brehon.aspx] (Accessed 21/01/16).

4. The present contribution will refer to the translation by Patrick C. Power, The Midnight Court, Cork, The Mercier Press, $3^{\text {rd }}$ edition 1986.

5. Daniel Corkery, The Hidden Ireland, M. H. Gill \& Son, Dublin, 1924, p. 62. 
consent, liberty and decision-making powers. Thus marriage, as it was understood and experienced, was a legally flawed contract due to women's legal minority, embodied by the legal concepts of "coverture" and "consortium".

\section{Women and legal minority within marriage}

The Common Law considers that unmarried individuals change their legal status upon marriage; women, in particular, lose their legal personhood and their rights are transferred to their husband. This doctrine, called "coverture", dates back to medieval Anglo-Norman law and was defined by William Blackstone, a renowned English jurist of the $18^{\text {th }}$ century, as follows:

By marriage, the husband and wife are one person in law: that is, the very being or legal existence of the woman is suspended during the marriage, or at least is incorporated and consolidated into that of the husband: under whose wing, protection, and cover, she performs everything; and is therefore called in our law-French a feme-covert; is said to be covert-baron, or under the protection and influence of her husband, her baron, or lord; and her condition during her marriage is called her coverture. Upon this principle, of a union of person in husband and wife, depend almost all the legal rights, duties, and disabilities that either of them acquires by the marriage. I speak not at present of the rights of property, but of such as are merely personal. For this reason, a man cannot grant anything to his wife, or enter into covenant with her: for the grant would be to suppose her separate existence; and to covenant with her, would be only to covenant with himself: and therefore it is also generally true, that all compacts made between husband and wife, when single, are voided by the intermarriage ${ }^{6}$.

The legal paradox was that unmarried plebeian women were allowed to work in domestic or farm service, which helped them to constitute their future dowry ${ }^{7}$. Yet, once married, women ceased to be financially and legally independent, according to English marriage law, especially with the notion of coverture. However, the other consequence of the legal incapacity of wives meant that husbands were responsible for all the past, present and future debts incurred by their spouse. Thus, why would women give up the comfort of financial independence for the legal servitude of married life? Pressure to conform to social norms is one pos-

6. Sir William Blackstone (1769). "Of Husband and Wife". Commentaries on the Laws of England (1765-1769). Lonang Institute, 2014. Available online at [http://lonang.com/library/reference/blackstone-commentaries-law-england] (Accessed 23/01/16).

7. Mary O’Dowd, A History of Women in Ireland 1500-1800, Harlow, Pearson Education Ltd, 2005, p. 12. 
sible explanation that pervades the poem. This is emphasized in the maid's second speech, in which she makes no secret that her unfortunate friend, a maid that had no personal fortune, accepted the old man's offer out of necessity ${ }^{8}$. But the way the man presented matrimony to her was solely based on material comfort and social status $^{9}$. The quest for matrimony is described as a race among women of marriable age, where appearances as well as family background play no small part in the process. Following an old poetic tradition where the beauty of women is extolled, the maid is reduced to advertising her own looks ${ }^{10}$ as well as her clothes ${ }^{11}$. Besides, she has to contend with the scorn of those women who were lucky enough to lure a man into wedlock ${ }^{12}$. Indeed the status of unmarried women was not enviable, because they did not comply with the social norm embodied by matrimony. Marriage was the only option available and the poem emphasizes the plight of single women without the legal protection of men, even if literature had somehow exaggerated it $^{13}$. The fate of these women was to be shunned by the community, which resulted in poverty, abuse and childlessness ${ }^{14}$ in old age. Marriage was, therefore, the perfect illustration of the economic law of supply and demand: with it, women secured an acceptable social status and material support in return for sexual intercourse, raising children and domestic service. This state of affairs was expressed in another legal doctrine called "consortium".

According to Common Law, consortium

encompasses services performed by a spouse. The Common Law did not recognize a wife's right to services on her husband's part. Because she was viewed as a social and legal inferior, she could not demand that he work for her and, therefore, she had no remedy for loss of sexual relations, affection, or services. The wrongdoer was liable only to the husband directly. A husband was considered to have suffered tangible damages for injury to his wife and, initially, had the sole right to bring an action for loss of consortium. The loss of services that had to be asserted included his wife's general usefulness, household services such as cooking and cleaning, industry, and frugality. Eventually, the assumption evolved that a man suffered these impairments upon injury to his wife, and damages were recoverable by him for any period in which he was divested of sex,

8. Line 695: "Ach easnamh an tsaoil 'is ba dhéirc léi an tsastacht" ("But worldly want; 'twas an alms to have comfort!")

9. Lines 701-708.

10. Lines 229-240.

11. Lines 255-268.

12. Lines 323-330.

13. Anne Laurence, "Women and the Transmission of Property: Inheritance in the British Isles in the $17^{\text {th }}$ Century". Dix-septième siècle, 244(3), 2009, pp.435-450. Available at [www.oro.open.ac.uk] (Accessed 28/11/2011).

14. Lines 312-319. 
fellowship, and affection, in spite of the fact that his wife might not be responsible for housekeeping ${ }^{15}$.

In the poem, the old man deplores his young wife's deceitful attitude and adultery because she was already pregnant when she married him, a claim that could have been vindicated by a court of law. However, the young woman who complains that she had been deprived of sexual pleasure by her ageing husband's impotence would not have had any legal ground to complain at Common Law. The fact that she never experienced sexual pleasure, as she claimed was her right ${ }^{16}$, could not grant her any legal relief.

Men were thus in a stronger position than women: they could select their future partner on stricter criteria, family background, wealth and reputation being the most important of all, as the old man's speech clearly shows ${ }^{17}$. Another reason, put forward by the old husband, for postponing marriage had a lot to do with the cost of the ceremony and of supporting a family ${ }^{18}$ when no reward could be gained. Besides, one consequence of the legal incapacity of wives meant that husbands were responsible for all the past, present and future debts incurred by their spouse. But financial incentive for the less wealthy party to marry into money was not the sole prerogative of women: the maid complains of young men marrying much older women for their wealth ${ }^{19}$. Thus as a contract, marriage was too onesided to be endorsed by any rational party. Besides, the issue of consent, which is still a legal requirement for the celebration of either civil or church marriage, is largely exposed as a legal fiction. The poem describes at length how women are led to agree to unattractive conjugal ties. In a very Rousseauistic way, the poem criticizes the power of money that corrupts the institution of marriage by dissociating material comfort from natural instincts like sex and maternity ${ }^{20}$. For the maid, marriage should celebrate nature's triumph and fulfil women's natural individual rights. This is evidenced by the resort to words like "ceart" (right) and "dual" (natural, proper), which merge the lexical fields of law and nature and give precedence to the latter. But inequality within marriage is not limited to the status of spouses; it also affects notions like parenthood and the differential treatment of legitimate children and those born out-of-wedlock.

\footnotetext{
15. [http://legal-dictionary. thefreedictionary.com/consortium] (Accessed 24/01/16)

16. Line 726: "Ar nós ba dhual dhá uair san oíche?" ("Twice in the night as was her right").

17. Lines 371-415.

18. Lines 501-510.

19. Lines 199-222.

20. "Je voudrais une chose bonne dans sa qualité ; avec mon argent je suis sûr de l'avoir mauvaise. J'achète cher un œuf frais, il est vieux, un beau fruit, il est vert; une fille, elle est gâtée”. Rousseau, J.J. Les Confessions, Livre I, Paris, Garnier Flammarion, p. 73.
} 


\section{The status of children within marriage law}

Another thorny issue in marriage concerned the legitimacy of children. The old man does not only vilify women's promiscuous nature, but the manner in which they manage to dupe an older, richer man into becoming the legal father of their offsprings conceived out of wedlock ${ }^{21}$. The law turns against husbands as their status obliges them to act as fathers to other men's children under the doctrine of legal parenthood. Women collectively contribute to bringing about this situation by inventing all sorts of lies to make the husband believe he is the real father. The purpose of matrimony, which was meant to create a family and beget children who would perpetuate the genetic lineage of a man and the transmission of his property, is contradicted by the real-life experience of adultery. One cannot doubt who the mother of a child is, but fathers are always putative. Paternity is a legal construct that is belied by the tricks of nature: indeed, many stories were propagated in order to deter women and men from having adulterous intercourse. One of them maintained that children born in such circumstances would be unhealthy, handicapped and would not live long. However, the old man's speech testifies to the robustness and health of love-children ${ }^{22}$. Common Law had no other means of dealing with adulterine children other than ignoring their existence, unlike the old Brehon Law which gave a status to all children: according to it, no child was barred from inheritance and child maintenance ${ }^{23}$. Besides, monogamy was not an obligation, and early Irish law tracts provided for every kind of person, who would find their place within the social structure. But the legal importance of legitimate children in the eye of the Common Law had important consequences regarding the inheritance of land and support rights for mother and child.

\section{Marriage and land ownership issues}

The ownership of land had always been a crucial and sensitive issue in England, and the passing of the Penal Laws in Ireland contributed to its legal importance. The entire system of inheritance privileged the eldest son (male primogeniture) and prevented land from passing into the hands of a woman. This privileged status of certain male heirs was strengthened by the legal concept of "entailment". It meant that the landowner could will his real estate to one of his sons; the aim was to bar daughters or children from a subsequent marriage from inheritance ${ }^{24}$. The underlining idea was to maintain the land within the family,

21. Lines 471-472 and most of the old man's speech.

22. Lines 609-618 and 639-652.

23. Fergus Kelly, A Guide to Ancient Irish Law, Dublin, DIAS School of Celtic Studies, 1988, p. 85.

24. See [http://www.math.grinnell.edu/-simpsone/Teaching/Romantics/josh.html] (Accessed 24/01/16). 
which was symbolically the owner of a land that could grant titles and privileges. In Ireland, there were further restrictions on land succession that stemmed from the Penal Laws:

Catholics could neither teach their children nor send them abroad; persons of property could not enter into mixed marriages; Catholic property was inherited equally among the sons unless one was a Protestant, in which case he received all; a Catholic could not inherit property if there was any Protestant heir; a Catholic could not possess arms or a horse worth more than $£ 5$; Catholics could not hold leases for more than 31 years, and they could not make a profit greater than a third of their rent. The hierarchy of the Catholic Church was banished or suppressed, and Catholics could not hold seats in the Irish Parliament (1692), hold public office, vote (1727), or practice law. Cases against Catholics were tried without juries, and bounties were given to informers against them ${ }^{25}$.

Although the poem does not directly raise this issue, it alludes to the unequal treatment of persons of different denominations sanctioned by the law. Protestantism is associated with Anglicanism; the Church of Ireland has shaped the institution of marriage and the old man proposes to abolish matrimony altogether and let nature take its course. This would remove social barriers that confined marriage matches within the limits of social classes and contribute to the breeding of strong children that would give new vigour to the Irish race, while removing the burden of child support from ageing legal fathers ${ }^{26}$. One consequence would be to do away with the current hypocrisy of the law, whose purpose turned out not to promote anyone's happiness. The old man's grudge against marriage and women is not only based on the latter's propensity to squander money, but also on their natural tendency to cheat on their husbands and get pregnant as a result. He sees a contradiction between the law of the Church that prohibits adultery and divorce at the same time. This had always been the policy of the Catholic Church, but, strangely enough, this point of view had been adopted by the Anglican Church as well. Contrary to other Protestant denominations that allowed divorce, the Churches of England and Ireland considered marriage as indissoluble, even if a legal separation or annulment could be pronounced in certain cases, like insanity or impotence ${ }^{27}$.

25. See [http://www.encyclopedia.com/topic/Penal_Laws.aspx] (Accessed 24/01/16).

26. Lines 663-670.

27. "Thomas Cranmer, first Archbishop of Canterbury following Henry's break with Rome (and martyred by Mary Tudor in 1556), played a key role in the formulation of Anglican views on divorce and remarriage. His attitudes reflected an affinity for Roman Catholic theology. He was a major figure in the council of prelates, which wrote The Institution of a Christian Man in 1537, and was chairman of the commission which produced A Necessary Doctrine and Erudition of Any Christian Man in 1543, both of which were authorized by the King. Both books were similar in their emphasis that any marriage to which there was an impediment according to 
This also translated into law as the Anglican Church was at the head of ecclesiastical courts that heard cases of separation, adultery and the validity of marriages. The sacramental and public quality of marriage that became the law in 1753 with the Marriage $A c t^{28}$ is in sharp contrast with the subsequent misery that befalls cuckolds $^{29}$ who cannot repudiate their unfaithful wives. This explains why the old man calls for the abolition of marriage all the more so as divorce had already been advocated by Milton in his tracts on the subject published in $1643-45^{30}$. But marriage is neither limited to a sacrament nor to a legal concept. It is also a social construct that had long-lasting effects on the fabric of Irish society in the $18^{\text {th }}$ century.

\section{圈 Marriage law as social hypocrisy and a source of immorality}

What characterizes the attitudes of the old man and the maid at the Midnight Court is their discontent about the state of affairs brought by matrimonial laws. The old man complains of women's frivolous conduct; according to him their only objective is to lure weak old men into marriage; this leads to unjustified paternity as well as to disproportionate expenditures. As to the maid, she deplores that the present state of the law only encourages immoral conduct. She maintains that her impotent old husband has forced her to commit the sin of adultery ${ }^{31}$, which sharply contrasts the words of the Apostle Paul who chastises adultery but extols marriage ${ }^{32}$. She contends that the plight of unmarried women made them easy preys for men without scruples. In her quest for a husband, the maid tries hard to charm the men she meets, in the hope that one may respond to her beauty and good manners. She tells of her heart-breaking experiences ${ }^{33}$ simply because she had been promised marriage by men who only thought of using her.

the laws of either church or realm must be declared null (and it was under this provision that Henry had his marriage to Catherine of Aragon declared null), but if a marriage was lawfully made according to the ordinance of God, it could not be dissolved during the lives of the spouses" [http://theologicalstudies.org.uk/article_divorce_snuth.html] (Accessed 23/01/16).

28. Lines 469-470: "Ó léadh ar bord os comhair na ndaoine, An t-Ego Vos so a ordaigh Íosa" ("From when publicly read before the people/ The I join you ordained by Jesus").

29. Lines 511-514.

30. A complete electronic version of those tracts can be found at [https://muse.jhu.edu/books/9780820705280] (Accessed 20/10/12).

31. Lines 693-694.

32. Lines 887-890.

33. Line 282: "Dhalladar riamh é 'is mo thurrainn, mo ghrá dóibh" (“They always fooled me; my heart they crushed”). 


\section{The ambiguous role of the Anglican institution}

But one institution was at the origin of the confusion, and this was the Church of Ireland. There was clearly a conflict between law and everyday practice that could turn marriage to a dishonest man's advantage. Indeed English law accepted two sorts of valid marriages, depending on which jurisdiction heard the case. For ecclesiastical courts under the authority of the Anglican Church, a marriage was valid if both betrothed had publicly exchanged vows to take each other as spouses before an Anglican minister ${ }^{34}$ (de praesenti). This could sometimes be done without the consent of parents or even in the absence of witnesses ${ }^{35}$. Thereafter the marriage was deemed indissoluble according to the law of the Church. Daniel Defoe ${ }^{36}$, among others, strongly opposed the toleration of secret marriages, which were celebrated between eloping lovers and poor people. He compared such a practice to legalised prostitution until it was abolished by the Marriage Act in 1753, but the practice itself may well have survived for a while. At least it may have encouraged sex before marriage, which was sometimes considered the quickest path to a hasty ceremony. On the other hand, Common Law courts imposed the publicity of marriage for it to be valid and enforceable, especially when property, widows' rights and inheritance were at stake. This necessitated the publication of banns and a solemn ceremony in open church where the banns were proclaimed three Sundays in a row. Such a path was preferred by wealthy middle-class families and the landed gentry. In Ireland, due to the strict control of land ownership and the legal limitations put on Catholics to own land and transfer real property to their heirs, legislation ${ }^{37}$ made the publication of banns and the obtaining of a licence by an Anglican minister or bishop compulsory ${ }^{38}$. Legislation likewise prohibited inter-religious marriage, at least in theory. But there were many ways to circumvent the law. Secret marriages were valid in the eyes of the Anglican Church until 1753 only insofar as both betrothed gave their full and enlightened consent to their marriage vows when the ceremony was performed. If one of the spouses later admitted that he did not fully comprehend what those vows entailed, any Ecclesiastical Court would invalidate the marriage, a process that was relatively frequent and called into question the solidity of matrimony. In Britain, secret marriages following the granting of a license by an Anglican minis-

34. This form of marriage was called "contract" or de praesenti marriage.

35. Melissa J. Ganz, "Moll Flanders and English Marriage Law". Eighteenth Century Fiction: Vol.17: Iss.2, Article 2, 2005. Available at [http://digitalcommons.mcmaster.calecflvol17iss2/2], p. 4 (Accessed 26/11/2014).

36. Conjugal Lewdness, 1731; Janvier, Meredith, 1872-1936, bookseller, 1731. Availbale online at [https://archive. org/details/treatiseconcerni00defo] (Accessed 28/01/16).

37. Act 9 Geo.II, c.11. Available online at [http:/library.law.umn.edu/irishlaw/intro.html] (Accessed 24/01/16).

38. W. Harris Faloon, The Marriage Law of Ireland: With Introduction and Notes, Dublin, Hodges Figgis, 1881, p. 39. 
ter or bishop enabled those who did not conform to social or legal criteria to get married $^{39}$. This could include pregnant brides, soldiers on leave from the Army or Navy, when the parties greatly differed in age or social standing, those who did not secure permission from their parents or guardians or those who differed in faith. The maid deplores the practice of marrying into money, which sometimes meant that the spouses were of a different denomination. This included the marriage of Catholics and Protestants ${ }^{40}$ in Ireland, a practice known as hypergamy, or "marrying up". Although it was not widespread, this custom usually involved a Church of Ireland man marrying a Catholic woman of lower social extraction:

Hypergamy is the observed effect whereby for evolutionary reasons and social pressure women tend to marry men of a higher status and rarely lower. This custom existed in a society where class division was largely drawn along ethnic and religious boundaries. The Church of Ireland Anglo-Irish Protestants were the elite and Irish Catholics were largely landless peasants. From 1559 the Penal Laws were an evolving series of statutes that in various periods barred Catholics from voting, serving in Parliament or the legal profession, possession of firearms or a decent horse and banned mixed marriages. The Penal Laws sought to disinherit the Catholic population of land and encourage conversion to the Church of Ireland. Religion was both the marker and maker of class. As the Penal Laws favoured Protestant landownership, a family unit consisting of Protestant men and Catholic women ensured the land would stay in the family, whilst the reverse would certainly result in the loss of land and access to elite institutions ${ }^{41}$.

One way of attenuating the social stigma of such marriages was to diversify the religious education of children born from such unions: generally boys would follow their father's religion while the daughters would take their mother's. One well-known example is that of philosopher Edmund Burke ${ }^{42}$, but it also shows

39. A license was not made public and shortened the delay between the granting and the marriage ceremony. See [https:I/familysearch.org/learn/wiki/en/Marriage_Allegations,_Bonds_and_Licences_in_England_and_Wales] (Accessed 25/01/16)

40. This situation is alluded to in traditional songs in the Irish language. For example, a Connemara song like "Sí do Mheamó í mentions a rich old woman marrying a much younger man. One verse says that the old woman "eats meat on Friday and Saturday" (Is d'iosfaith sí feoil on Friday and Saturday"). This means that she is Protestant as she does not fast on those two days, contrary to what the Roman Catholic rite demands.

41. J. Buck, "The Role of Ne Temere in the Decline of a Custom in Ireland for the Religious Affiliation of Children in Mixed Marriages" (no date): p. 1. [http://www.academia.edu/2118997/The_role_of_ne_temere_in_the_decline_of_an_Irish_custom_regarding_the_religious_affiliation_of_the_children_of_mixed_marriages] (Accessed 26/01/16).

42. "Born in Dublin to a Church of Ireland father and a Catholic mother in 1729, surrounded by Catholic sisters and Protestant brothers, he represents the most oft-cited example of this custom. Perhaps the role of his mother in his religious and cultural instruction influenced Edmund Burke's decision to marry a Catholic. In 
that, out of necessity, laws could be circumvented, sometimes with the blessing of the Anglican Church. The issue of marriage is not solely confined to the province of the law, but it is clearly political, economic and social. The maid argues that social constraints and poverty force young men and women to look for a wealthier spouse so as to secure a better material lifestyle. This is all the more striking as early marriages were favoured by the Irish peasantry before the Famine $^{43}$. In her opinion, this is evidence that the true purpose of religious marriage has been diverted. Her argument is that this state of affairs runs counter to the law of God proclaiming that marriage was the sanctification of family and children ${ }^{44}$. Church law, whether Catholic or Anglican, is based on the doctrine of natural law (jus naturalis), according to which "certain rights or values are inherent by virtue of human nature, and universally cognizable through human reason. Historically, natural law refers to the use of reason to analyze both social and personal human nature to deduce binding rules of moral behaviour ${ }^{45}$ ". Evidently for the maid, marrying for financial reasons a much older man or woman violates natural law because it will exclude sexual pleasure and children. The maid's speech exposes the paradox of a law that does not take morality and human nature into consideration while diverging from its stated purposes of strengthening law and morality. This leads us to the second target of the maid's fierce criticism, the position of the Catholic Church on the celibacy of priests and its attitude to women for the same reasons.

\section{The Catholic Church and the celibacy of priests}

Women have long been considered with mixed feeling by the Early Church. They were the source of Man's Fall from Paradise, as shown by some misogynist quotes from the Church Fathers ${ }^{46}$. In Ireland, Brehon Law never treated women and men as

his biography of Burke, O’Brien proffers the evidence of Conformity Rolls to suggest that his father converted from Catholicism to the Church of Ireland in order to continue practising as a lawyer. He argues that Burke's father belonged to the established Catholic gentry and his nominal conversion allowed him and his sons to avoid the Penal Laws. Whether Burke's father converted does not undermine the centrality of the contention, that the custom existed and was a pragmatic compromise that allowed couples and families to co-exist whilst having different religious beliefs." Ibid., p. 2.

43. H.K. Connell, "Marriage in Ireland after the Famine : The Diffusion of the Match" Read before the Society in Dublin on 10th December 1955, and in Belfast on 20th January, 1956, p. 83. Available online at [http://www. tara.tcd.ie/bitstream/handle/2262/4266/jsisivolxvixpart4_82103.pdf?sequence=1] (Accessed 20/01/16).

44. The Catechism of the Catholic Church stipulates that "The matrimonial covenant, by which a man and a woman establish between themselves a partnership of the whole of life, is by its nature ordered toward the good of the spouses and the procreation and education of offspring; this covenant between baptized persons has been raised by Christ the Lord to the dignity of a sacrament." [http://www3.nd.edu/-afreddos/courses/264/ ccc-matri.htm] (Accessed 29/01/16).

45. Leo Strauss, "Natural Law", International Encyclopedia of the Social Sciences. Macmillan 1968.

46. "In pain shall you bring forth children, woman, and you shall turn to your husband and he shall rule over you. 
equals ${ }^{47}$, but it is safe to say that women were not completely absent from the public sphere in terms of access to law, professions and property ownership ${ }^{48}$. But, from the onset, the Church had sought to keep women away from spiritual debates, unless they were strictly controlled by its hierarchy. This was largely due to the creation of a wholly negative "female nature", whose purpose was to distract men from their spiritual goals; the depreciation of female values was largely based on the concept of folly ("baoise") attributed to women to deny them intelligence, spirituality and a sense of responsibility ${ }^{49}$. In the poem, the maid highlights the long tradition of clerical distrust of women, while lamenting the persecution of the Catholic clergy by the authorities under the Penal Laws ${ }^{50}$. But she also stresses that the actions of priests were not always in keeping with the official instructions from Rome. She attributes clerical misogyny to the frigidity of some ${ }^{51}$, and not to a theological argument. She also denounces the hypocrisy of others who use their social status to help themselves to earthly pleasures ${ }^{52}$, which cannot fool women ${ }^{53}$. The maid draws a parallel between the priests' sexual prowess and their generosity and altruism: these priests embody the love for a God-given life, as opposed to those who turn to death and desolation. The Church's imposition of celibacy has a twofold, negative consequence: first, priests are confronted with a contradiction in terms if they promote abstinence and chastity while enjoying secret trysts with married women. Secondly, by doing so, they doubly violate the sanctity of marriage by enticing women to commit adultery and inpregnating them ${ }^{54}$. The maid's last argument is more concerned with theological references: the Bible enjoins man and woman to procreate, Saint Paul reaffirms the sanctity of marriage and condemns adultery. Moreover, Jesus was born of Mary, who was also a married woman ${ }^{55}$. Nature and biblical law converge in making marriage the best

And do you not know that you are Eve? God's sentence hangs still over all your sex and His punishment weighs down upon you. You are the devil's gateway; you are she who first violated the forbidden tree and broke the law of God. It was you who coaxed your way around him whom the devil had not the force to attack. With what ease you shattered that image of God: Man! Because of the death you merited, even the Son of God had to die... Woman, you are the gate to hell." Tertullian (c160-225): On the Apparel of Women, chapter 1.

47. Roisin McLaughlin, Early Irish Satire, Dublin, DIAS, 2008, p. 31.

48. Loretta Wilson, 1989, [http://www.irish-society.org/home/hedgemaster-archives-2/history-events/the-brehon-laws] (Accessed 20/01/14).

49. Máirín Nic Eoin, B’Ait Leo Bean, Gnéithe den Idé-eolaiocht Inscne i dTraidisiún Litheartha na Gaeilge. Baile Átha Cliath: An Clóchomhar Tta, 1998, p. 11-13.

50. The celebration of a mass could lead a priest to gaol or the gallows (Line 857-862). Traditional songs also depict this situation, notably in An Raibh Tú ar an gCarraig?, a song popular in Co. Kerry.

51. Line 862 .

52. Lines 843-846. The priest who must either turn away from his beloved to comply with canon law or become a Protestant minister and get married is a very common theme in Irish traditional sean nós singing (with songs like An Sagairtín or Fill, Fill Á Rún in the Connemara tradition).

53. Line 847: "'Is tá a fhios againn gur fuil 'is feoil iad!" ("It's well we know they're flesh and blood!").

54. Lines 871-872. The maid goes as far as accusing them of going against the biblical promotion of procreation by choosing their partners among middle-aged women, who can no longer bear children (lines 873-876).

55. Lines 883-899. 
achievement for humanity, and so, any attempt to revile women is to defy the law of God, according to the maid's final syllogism. But this would only contribute to the social, economic and political demise of Ireland should clerical celibacy and hypergamy continue to prosper. They are against nature and subvert of the principles of marriage and matrimonial law, and the poem proceeds to formulare their judicial indictment by an all-Irish, all-female court of law.

\section{The judicial redress brought by the fairy court}

The fairy court described in the poem is a response to the plaintiffs' discontent with a marriage law that had been gradually subverted from inside the institutions of the Church and by the Common Law. Merriman borrows many of its features from the Brehon courts and laws that were operating in Ireland prior to the English conquest. These courts survived until the end of the $17^{\text {th }}$ century in competition with the British court system. Records show that their influence was still great in 1612 and their records were read notably in matters of land boundaries $^{56}$. Such an antiquated court system nevertheless inspired the Dáil courts of the Irish Republic during the War of Independence ${ }^{57}$. Even though Merriman was no lawyer, he may have retained some knowledge of the proceedings, the layout of the courtroom and key legal concepts, like many other hedge schoolmasters ${ }^{58}$. The poem is thus loosely inspired by Brehon law and it may be that Merriman used it as a pretext to satirize a social situation he wished to reform. Comic relief plays no small part in conveying those ideas to the largely rural audience that would learn the verses and propagate them across Munster. One essential feature of the poem is that it describes a secret court session and a rather unusual one. Proceedings do not follow the habitual legal course of action, they are held at night by an all-female court personnel. The language of the court is Irish and, while it was banned from official life in Ireland, it turns out to be an essential ingredient to satire, the legal remedy granted by the court.

\section{Time, place and proceedings}

The supernatural court hearing takes place at night somewhere in a hidden mound in the Clare countryside ${ }^{59}$. This is how most medieval texts describe the

56. Daniel Flynn, 'Redwood Castle, The Heart of Ireland's Heritage- Brehon Law, 2009. Available at [http://www. redwoodcastleireland.com/brehon-law-page.html] (Accessed 26/11/2015).

57. Mary Kotsonouris, Retreat from revolution: the Dáil courts, 1920-24, Dublin, Irish Academic Press, 1994.

58. Antonia McManus, The Irish Hedge School and Its Books (1695-1831), Dublin, Four Courts Press, 2004, p. 96.

59. The poem mention the church's gable at Knockmanwee (line 138), the Queen's palace at Lough Greaney (72) and the village of Feakle (131). 
encounter between a human and creatures from the Otherworld: the court is presided over by Aoibheall, a Fairy Queen. As such, she renders supernatural justice to all those that believe in her existence. Besides, the nature of the legal dispute seems unrealistic and typical of the topsey-turveydom of dreams where women win their case against men and the law. Midnight is rife with otherworldly stories in which normal values are completely reversed. Aoibheall acts as a travelling judge, setting up her court in various locations whenever a serious offence against justice has been committed. She also recalls the royal figure of Ireland as depicted in the aislingi but, contrary to the pitiful image she gives in those poems, she is featured as a warrior-queen and a dreaded judge. She is praised as a royal commander and a seer ${ }^{60}$ but this is not in line with the old Brehon tradition, since women could not be professional judges. This indicates that the court is not a real one, along with the secrecy surrounding its proceedings. The courtroom is situated in an unchartered territory or another dimension as the poet and the bailiff enter a large room. This is reminiscent of Irish myths in which the story takes place in the Otherworld of the Sid located underground near a mountain, a river or a stream ${ }^{61}$. The room is not described in detail but it seems aristocratic and richly decorated. The only areas that are mentioned are the bench with the throne on which the fairy judge sits ${ }^{62}$ and the witnesses stand ${ }^{63}$. Unlike a real Brethon courtroom ${ }^{64}$, very little is said about the layout, as though only the most essential elements suffice to give the whole fairy court a slightly legal appearance. But this is not the only characteristic of the Midnight Court that differs from the Brehon court proceedings. Both plaintiffs, the old man and the maid, expose their complaints and grievances themselves, whereas Brehon law required litigants to choose a skilled advocate to represent them and bring their witnesses and sureties ${ }^{65}$. And while strict adherence to procedure was considered the key to a successful case, the self-represented plaintiffs mention the opinions of friends and acquaintances but this is only hearsay ${ }^{66}$. Nevertheless, the hearing follows a well-established pattern among Brehons. Each case began with the tacrae, or exposition of the facts; this corresponds to the maid's first speech ${ }^{67}$. This was followed by the freacrae, or counter-pleading, during which each party rebuts each other's arguments,

60. Lines 168 and 171.

61. Particularly in Lebor Gabála Érenn, from the Book of Leinster, ed. R.I. Best, Osborn Bergin, M.A. O’Brien and Anne O'Sullivan (1954-83). The Book of Leinster, formerly Lebar na Núachongbála. 6 vols. Dublin, DIAS.

62. "binse an tsaorchirt" (line 144).

63. "clár na míonn” (line 152).

64. For the description of a Brehon court, see Fergus Kelly, A Guide to Early Irish Law, Dublin, DIAS, 1988, p. 194.

65. Ibid., p. 195.

66. Lines 349 and 431.

67. Lines 167-356. 
something that would encompass the old man's speech ${ }^{68}$ and the maid's second intervention ${ }^{69}$. Then comes breth, or the judgment with its promulgation, called forus, as well as the sentencing ${ }^{70}$. Yet if the judicial pattern is more or less respected, there is a paradox between the civil nature of the case and the punishment. Brehon courts did rarely hand down sentences involving death, corporal punishment or even imprisonment; their rulings dealt with the payment of damages to the aggrieved party, and these were calculated according to the social rank of the parties symbolized by their "honour price ${ }^{71}$ ". Obviously the maid does not seem to be on equal footing with the old man, so it becomes clear that the aim of the poem is to satirize a social phenomenon and put it to rights.

\section{The judicial role of satire, language and female symbolism}

The poem openly criticizes the corruption of the law and of the lawyers. The old man in the poem is wealthy and owns land ${ }^{72}$, and he has easy access to the court thanks to his acquaintances in the legal spheres ${ }^{73}$. For most people, dealing with the law was an indirect process, mostly because they could not speak English and were not educated enough to understand its arcanes. Many initial pleas were drawn up by hedge schoolmasters who received fees for drafting legal documents $^{74}$. But the poem reproaches the lawyers for being disingenuous and inclined to receive bribes ${ }^{75}$. By contrast, the fairy court seems more democratic because it does not distinguish between rich and poor, aristocrats or commoners ${ }^{76}$, and each is given the opportunity to voice their concerns. The poem insists on what presides over the good workings of justice: absence of disagreement, rightful ownership of land, social order and the control of law ${ }^{77}$. This may well describe the political landscape of $18^{\text {th }}$ century Ireland, where politics was

68. Lines 363-430.

69. Part 3, lines 683-826.

70. Part 4 of the poem, lines 927-1090.

71. "The measure of a person's status was known as his 'honour price' /lóg n-enech, the literal translation of which is 'the price of his face'. Brehon law prohibited a person from entering into a legal contract for an amount which exceeded his honour price and he could not go surely for a greater amount either. The honour price was also important in ascertaining the punishment attached to major crimes; a serious offence which was committed against a person of high rank demanded a greater punishment than the same offence committed against a person of lower rank. Rank was also hugely important when it came to the law of evidence, with the oath of a high ranking person automatically outweighing that of a lower ranking person". Noelle Higgins, "The Lost Legal System: Pre-Common Law Ireland and the Brehon Law" 2014. Published online at [http://www.academia. edu/2405281/_The_Lost_Legal_System_Pre-Common_Law_Ireland_and_Brehon_Law_] (Accessed 28/01/16).

72. Lines 477-485.

73. "Cairde i gcúirt agus cúnamh dlí agam”, lit. "I had friends in court and legal seccour" (line 481).

74. Dowling, P.J. The Hedge Schools of Ireland, Cork \& Dublin, Mercier Press, 1968, p. 87.

75. Lines 66, 89-93.

76. Lines 64-72.

77. Lines 70-81. 
discussed among the landed gentry, and women were not simply passive observers but actively engaged, behind the scene, sin the debates of the day ${ }^{78}$. However, truthful testimonies were of paramount importance to the fairy court. This may refer to the disaster brought to society and to the land when false oaths were taken in early Irish texts, where war and desolation were caused by the breaking of a pledge or a prohibition ${ }^{79}$. In the poem, the old man seems to have acted legally but against the laws of nature because he has deceived a young maid into marrying for money while depriving her of her right to have sex and children. In a way, the old man and the maid epitomize the unenviable situation of Irish peasants in the $18^{\text {th }}$ century, whose fertility represented a great potential for economic wealth. But their poverty and the absence of adequate policies from the landed gentry or from the British government could only cause Ireland to remain politically and economically marginal ${ }^{80}$. The only way to restore the truth about the perversion of the natural order brought about by social, economic and misogynist constraints was for the poet to adopt a frank and colourful language in the guise of satire.

Satire was not simply a literary amusement in a society that was attached to its folk tradition. Apart from retaining a strong belief in the fairy world, Irish people have attributed special powers to poets since pre-Christian times. Although medieval texts distinguish poets (fili) from jurists (brithem), other sources show that their competences overlapped ${ }^{81}$. Moreover, ancient poets shared with druids the capacity to use magic as a protection and a weapon against enemies: fili were also seers and had access to spells enabling them to foresee the future ${ }^{82}$. One very efficient way of defeating an enemy was to satirize him, a practice that survived well into Irish poetry of the $17^{\text {th }}$ to the $19^{\text {th }}$ century ${ }^{83}$. Poets had the power to

78. Mary O'Dowd, A History of Women in Ireland (1500-1800), Harlow, Pearson Education Ltd, 2005, p. 53-54.

79. A narrative like Togail Bruidne Da Derga explicitly refers to that practice: when Conare, son of Nemglan and Mess Buachalla is chosen as king, the druids said that his "bird-reign" ("énfhlaith") would be happy if he refrained from interfering in disputes and visiting some forbidden places. The fact that he didn't, caused the eruption of armed raids against his kingdom, the treason of his foster-brothers and his violent death at the Hostel of Da Derga at Brú na Bóinne in Co. Meath (Eleanor Knott [ed.], Togail Bruidne Da Derga, Dublin, Dias Mediaeval and Modern Irish Series, vol. VIII, 1975).

80. At the end of the mythical Battle of Moytura (Cath Mag Tuired) describing the victory of the Tuatha Dé against the Fomoire, Morrigan (lit. "the Great Queen") prohesizes the end of the world in the following terms: "I shall not see a world/Which will be dear to me:/ Summer without blossoms,/Cattle will be without milk,/ Women without modesty,/Men without valour./Conquests without a king [...] Woods without mast./Sea without produce [...] False judgements of old men./False precedents of lawyers,/Every man a betrayer./Every son a reaver./The son will go to the bed of his father,/The father will go to the bed of his son./ Each his brother's brother-in-law./He will not seek any woman outside his house [...] An evil time,/Son will deceive his father, /Daughter will deceive...” translated by Elizabeth A. Gray, Cath Maige Tuired: The Second Battle of Mag Tuired, [http://www.ucc.ie/celt/online/T300010.html], 2003, p. 73 (Accessed 10/10/14).

81. Fergus Kelly, op. cit., p. 48.

82. Ibid., p. 44-45.

83. Dáithí Ó hÓgáin, An File, Staidéar ar Osnádürthacht na Filíochta sa Traidisiún Gaelach. Baile Átha Cliath, Oifig an tSoláthair, 1982, p. 310-311. 
"rhyme someone to death", so formidable was their speech, or to cause blemishes to appear on their victims' face or body. Under the Penal Laws, poets were still feared for the venom they could put in their satires, which could bring mockery, dishonour and ostracism on their targets. The reasons for these satires to be composed are a mixture of personal rancour, religious or political arguments. The most common instances concerned turncoat priests, Protestant ministers, lewd wives, arrogant or miserly priests, English landlords, bailiffs and lawyers ${ }^{84}$. From a more political perspective, the performative nature of poetic language enables it to challenge the dominant status of English in public life.

In Cuirt an Mheain Oiche, satire operates at two levels in the narrative: in the story itself, where the bailiff and the maid launch the most violent diatribes against the injustice imposed on Ireland and her women; likewise, the whole poem is a satire composed by Merriman, who uses his characters to voice his criticism against both men and women. Most of all, resorting to laughter and ridicule facilitates the expression of frustrations that would otherwise have been hushed up ${ }^{85}$. More importantly, it describes the way in which female characters could bring about such havoc without being perceived as a threat. In the poem, the narrator nearly gets lynched by a mob of irate women who reproach him for not being married, and Aoibheall clearly gives them the power to destroy all male offenders, something that may be perceived as extra-judicial retribution, like its modern version of "naming and shaming". These women are mad, angry and bawdy in their vindication of the law of nature; women are, in a comic way, presented as the champions of Ireland, those who will save her from despair and desolation because they embody fertility ${ }^{86}$.

This leads us now to consider the importance of sexually explicit language in the poem. If satire has a legal role to play, sexuality pervades the poem, sometimes in very crude terms. Women are associated with nature, as the maid clearly states that only death and pregnancy could quell women's sexual drive ${ }^{87}$. This suggests that it should be given a lot of consideration from a legal point of view. Ancient Irish law did not give much credit to female testimonies except in sexual matters; one cause for the invalidation of marriage was the incapacity for a man to consummate it due to age or physical defects ${ }^{88}$. The graphic description of

84. Ibid., p. 315.

85. Máirín Nic Eoin, B’Ait Leo Bean, Gnéithe den Idé-eolaiocht Inscne i dTraidisiún Litheartha na Gaeilge. Baile Átha Cliath: An Clóchomhar Tta, 1998, p. 171.

86. This may be a graphic reference to the Sile na Gigs (or Sile na Gigh), these obscene stone carvings of grimacing women exposing their genitals above the doors of churches, castles or rocks. If little is known of their origin, interpretations also vary when it comes to their function. They may be anything from protection against the evil eye, a fertility symbol, a warning against female lust. See [http://www.sheelanagig.org/wordpress/theories/] (Accessed 20/01/16).

87. Lines 733-736.

88. Fergus Kelly, op. cit., p. 207. 
the maid's sexual frustration and attempts at reviving her old husband's vigour can thus be considered as a valid witness statement, and not only as a comic element ${ }^{89}$. It proves that nature should be the measuring rod when it comes to marriage and the law. By not taking this into account, men have brought sin into the world by enacting laws that purport to control women's sexuality. When fertility is attacked by the law, it means that the world order is turned upside down. Yet, can the poem be considered as a proto-feminist pamphlet?

Aoibheall's verdict is the fairy court's legal response to the chaos that reigns across Munster due to a dearth in marriages ${ }^{90}$. The decision is both a ruling and a statute ${ }^{91}$, solemnized by the presence of the bailiff and of the court recorder who officializes the date by which the decision becomes law. Aoibheal finds for the maid and debars the old man from getting any legal remedy. Her decree makes marriage a legal obligation for any man reaching the age of twenty-one, except for priests. Those who would not comply with the decision would be severely punished by the women. The latter may even decide what kind of corporal punishment they would inflict on old rakes, adulterers, boastful men or effeminate ones. This certainly rings like a revenge for the women of Ireland, but the judgement is so extreme that it tones down the overall defence of women's rights. That is why Cúirt an Mhean-Oíche can also be seen as a political pamphlet in disguise, and references to Brehon Law contribute to the discredit of Common Law as it operates in Ireland.

To conclude, one may say that Cúirt an Mheain Oíche is a perfect blend of literary tradition, social and political satire. It represents the revenge of the "hidden Ireland" that Corkery spoke of, which encompasses a people, a language and a culture that had been stripped of its pedestal and despised as Ireland lost its sovereignty. The workings of the court are the perfect expression of anger and frustration at a desperate state of affairs coupled with bleak prospects for the future. Women's bodies, desires and social conditions contribute to the seriousness of the criticism while toning down its edge. Indeed female symbolism is omnipresent in Irish poetry and is used for all sorts of reasons. It may idealise womanhood or revile women so as to justify their subjection. It may also expose problems that would normally be kept secret or underline the gravity of the political, economic

89. Lines 721-730, the maid specifies that women are entitled to have sex twice per night. This seemingly ravenous sexual appetite appears to represent a natural desire that will beget children that should be accepted by law. Patrick C. Power writes that "The dilemma of a man with regards to the paternity of a child is well and enigmatically expressed by some old Gaelic poet and is quoted by the Brehon laws: Saer brú beiris breith do thabairt cli - the fertile womb is free to bear a body! No matter what rule or law may decree, it can happen that the woman may have a child for anyone who takes her fancy. Laws and decrees cannot rule her fertility". Sex and Marriage in Ancient Ireland, Dufour Editions, Pennsylvania, 1997, p. 45.

90. Lines 925-1016.

91. "dli" (line 941) and "reacht" (line 1085). 
and moral situation of the country. This might explain why women, who have no real role to play, take it upon themselves to redress an otherwise desperate state of affairs. But, more importantly, the court that gathers at midnight, when reasonable people are asleep, the court that summons wild characters to its hearing is a court of poetry. It is a late survival of a once-flourishing tradition, a meeting where the best poets would recite their latest verse and compete fiercely against each other for the title of ollamh, or "chief poet". It may also be seen as the model for the Dáil courts of the early $20^{\text {th }}$ century. Where law and poetry converge is not only in the way poets and lawyers use speech to bring about the emergence of truth, but rather in their adversarial nature. And Brian Merriman, of whom very little is actually known, may well have won his case against legal injustice and the poetic contest of the period. 